\title{
Influence of Lamb Rennet Paste Containing Probiotic on Proteolysis and Rheological Properties of Pecorino Cheese
}

\author{
A. Santillo and M. Albenzio ${ }^{1}$ \\ Department of Production Sciences, Engineering, and Economics for Agricultural Systems (PrIME), University of Foggia, 71100 Foggia, Italy
}

\begin{abstract}
Pecorino cheeses made from heat-treated ewes' milk using traditional lamb rennet paste (RP), lamb rennet paste containing Lactobacillus acidophilus (LA-5; RPL), and lamb rennet paste containing a mix of Bifidobacterium lactis (BB-12) and Bifidobacterium longum (BB-46; RPB) were characterized for proteolytic and rheological features during ripening. Consumer acceptance of cheeses at $60 \mathrm{~d}$ of ripening was evaluated. Lactobacillus acidophilus and Bifidobacterium mix displayed counts of $8 \log _{10} \mathrm{cfu} / \mathrm{g}$ and $9 \log _{10} \mathrm{cfu} / \mathrm{g}$, respectively, in cheese during ripening. The RPB cheese displayed a greater degradation of casein $(\mathrm{CN})$ matrix carried out by the enzymes associated to both Bifidobacterium mix and endogenous lactic acid microflora, resulting in the highest values of non-CN N and watersoluble $\mathrm{N}$ and the highest amount of $\alpha_{\mathrm{s}}$-CN degradation products in cheese at $60 \mathrm{~d}$ of ripening. The RPL cheese displayed intermediate levels of lactic acid bacteria and of $\mathrm{N}$ fractions. The percentage of $\gamma-\mathrm{CN}$ in $\mathrm{RP}$ and $\mathrm{RPL}$ cheeses at $60 \mathrm{~d}$ was 2 -fold higher than in the cheese curd of the same groups, whereas the mentioned parameter was 3 -fold higher in RPB cheese than in the corresponding fresh curd according to its highest plasmin content. The lower hardness in RPB at the end of ripening could be ascribed to the greater proteolysis observed in cheese harboring the Bifidobacterium mix. Although differences in proteolytic patterns were found among treatments, there were no differences in smell and taste scores.
\end{abstract}

Key words: rennet paste, probiotic bacteria, Pecorino cheese, proteolysis

\section{INTRODUCTION}

Enzyme composition of rennet paste contributes to the development of typical flavor in cheese made from ovine milk (Addis et al., 2005; Santillo et al., 2007a,b).

Received September 28, 2007.

Accepted January 8, 2008.

${ }^{1}$ Corresponding author: m.albenzio@unifg.it
Milk coagulation is a major step of cheese manufacturing and largely determines the texture of the product (Lebecque et al., 2001).

Fermented dairy products enriched with probiotic bacteria have developed into one of the most successful categories of functional foods. Cheese could offer certain advantages as delivery systems of live probiotics to the gastrointestinal tract, having a higher $\mathrm{pH}$ than fermented milks and providing a more stable matrix supporting long-term survival (Corbo et al., 2001; Ross et al., 2002). The main probiotic organisms that are currently used worldwide belong to the genera Lactobacillus and Bifidobacterium (Shah, 2007).

Pecorino foggiano cheese, a traditional uncooked sheep's milk cheese, is of great value to the agricultural economy of the Apulia region of Italy. It is extremely valued in the local market and can be sold as shorttime ripened cheese with a soft texture and a thin yellow rind or as a long-time ripened cheese with a harder texture and a more piquant and intense flavor (Santillo et al., 2007a). The local genetic breed Gentile di Puglia is classified as one of the main fine-wooled ovine breeds (Fahmy and Shrestha, 2003); the small volume of milk yielded during lactation ( 80 to $100 \mathrm{~kg}$ ) is destined to lambs' feeding and for typical Pecorino cheese production (Chessa et al., 2003). Recent sources reported for Gentile di Puglia a total of about 6,000 animals reared in 35 farms located in Southern Italy (http://www.assonapa.it).

In this study, Lactobacillus acidophilus and a mix of Bifidobacterium lactis and Bifidobacterium longum were added into traditional lamb rennet paste. Pecorino cheese produced by Gentile di Puglia ewe milk coagulated with traditional lamb rennet paste or with rennet paste containing probiotic bacteria was characterized for proteolytic and rheological features during ripening. Differences in preference and acceptance of the cheeses at the end of ripening were also evaluated.

\section{MATERIALS AND METHODS}

\section{Lamb Rennet Paste Production}

The abomasa for rennet paste production were extracted from suckling lambs reared in the Apulia region 
(Southern Italy). The abomasa were processed at industrial plant scale according to a traditional protocol: the perivisceral fat was removed and the whole stomach was cut into slices, salt was added (18 to $20 \% \mathrm{wt} / \mathrm{wt}$ ), and the samples were ripened at $6^{\circ} \mathrm{C}$ and $70 \%$ relative humidity for 2 mo. Ripened abomasa were ground to obtain a paste. Lyophilized cultures of $L$. acidophilus (LA-5) and B. lactis (BB-12) and B. longum (BB-46; Chr. Hansen, Milan, Italy) were first propagated in De Man, Rogosa, Sharpe (MRS) broth (Merck, Darmstadt, Germany) with adjunct of maltose (20 g/L, mMRS) $\mathrm{pH}$ 5 and in MRS broth with adjunct of Cys $(10 \mathrm{~g} / \mathrm{L}$, cysMRS) $\mathrm{pH} 5$, respectively, under anaerobiosis at $37^{\circ} \mathrm{C}$ for $24 \mathrm{~h}$. Cells were harvested by centrifugation at 4,000 rpm for $10 \mathrm{~min}$, washed twice with sterile distilled water, and then inoculated in rennet paste at a concentration of $11 \log _{10} \mathrm{cfu} / \mathrm{g}$ of rennet paste. The paste containing probiotics was held for $24 \mathrm{~h}$ at $4^{\circ} \mathrm{C}$ before cheese production.

\section{Analyses on Lamb Rennet Paste}

Microbiology and Milk-Clotting Activity. Five grams of rennet paste was diluted in $45 \mathrm{~mL}$ of $0.9 \%$ (wt/vol) sterile saline solution and homogenized in a Stomacher Lab-Blender 400 (PBI International, Milan, Italy) for $1 \mathrm{~min}$. The aforementioned solution was also used to realize serial dilutions of sample that were plated on specific media for viable counts. The following media and conditions were used for analyses: plate count agar incubated for $48 \mathrm{~h}$ at $32^{\circ} \mathrm{C}$ for mesophilic bacteria; violet red bile agar incubated for $24 \mathrm{~h}$ at 37 and $44^{\circ} \mathrm{C}$ for total and fecal coliforms, respectively; M17 agar incubated, under anaerobiosis, for $48 \mathrm{~h}$ at $37^{\circ} \mathrm{C}$ for mesophilic lactococci; and MRS agar incubated under anaerobiosis for $48 \mathrm{~h}$ at $37^{\circ} \mathrm{C}$ for mesophilic lactobacilli.

Determination of total milk-clotting activity was carried out according to the IDF (2006, standard 199). The total milk-clotting activity of the test sample was calculated by interpolation relative to a bovine rennet with an enzyme composition of 75:25 (chymosin:pepsin) and a known milk-clotting activity. Results are reported as international milk-clotting units per gram of rennet paste.

Chymosin and Pepsin Activities in the Rennet Pastes. Aqueous rennet extracts $(20 \%$, wt/vol) were dialyzed for $3 \mathrm{~h}$ against $0.02 M$ piperazine buffer at $\mathrm{pH} 5.3$ through a dialysis tubing cellulose membrane (D9277, Sigma-Aldrich, Milano, Italy). Samples of the same rennet extract, both dialyzed and nondialyzed, were used to determine chymosin and pepsin activities according to the IDF (1997, standard 157a). Enzyme activity was reported as rennet units; 1 rennet unit is defined as the amount of enzyme contained in $1 \mathrm{~mL}$ of an enzyme preparation, which clots $10 \mathrm{~mL}$ of a reconstituted skim milk in $100 \mathrm{~s}$ at $30^{\circ} \mathrm{C}$.

\section{Analyses of Ewe's Milk}

Bulk milk and whey samples collected after milk clotting and extraction of the curd were analyzed for fat, protein, and lactose content (MilkoScan, FT 120, Foss Electric, Hillerød, Denmark); pH value (GLP 21, Crison, Barcelona, Spain); and somatic cell count (Fossomatic Minor, Foss Electric).

\section{Pecorino Cheese Production}

Gentile di Puglia ewe's milk was used for Pecorino cheese production. Three Pecorino cheesemaking trials were performed in triplicate at industrial plant scale according to the protocol reported by Santillo et al. (2007a) with modifications: milk was heated $\left(67^{\circ} \mathrm{C}, 20\right.$ $\mathrm{s})$, then cooled to $38^{\circ} \mathrm{C}$ prior to rennet addition, and after molding and pressing the curds, were held at $42^{\circ} \mathrm{C}$ for $5 \mathrm{~h}$. Cheeses were denoted RP - control cheese made with rennet paste, RPL-cheese made with rennet paste containing $L$. acidophilus culture (LA-5), and $\mathrm{RPB}$ - cheese made with rennet paste containing a mix of B. lactis (BB-12) and B. longum (BB-46). Cheeses were sampled and analyzed in duplicate at $1,7,15,30$, and $60 \mathrm{~d}$ of ripening.

\section{Analyses of Cheese}

Chemical Composition and Microbiology of Cheese. Dry matter content and $\mathrm{pH}$ of cheeses were determined according to IDF $(1986,1989)$. Total N (TN) and non-CN N (NCN) were determined as described by Gripon et al. (1975), and water-soluble N (WSN) was measured as proposed by Stadhouders (1960).

Mesophilic bacteria $\left(32^{\circ} \mathrm{C}\right.$ for $48 \mathrm{~h}$; plate count agar, Oxoid, Basingstoke, Hampshire, UK), total coliforms $\left(37^{\circ} \mathrm{C}\right.$ for $24 \mathrm{~h}$; violet red bile agar, Biolife, Milano, Italy), mesophilic lactococci and lactobacilli $\left(37^{\circ} \mathrm{C}\right.$ for 3 d; M17 agar and MRS agar, Merck) were enumerated. The enumeration of L. acidophilus and Bifidobacterium during cheese ripening was carried out using mMRS and cysMRS media, the pour-plate technique, and the results from plate counts were confirmed by microscopic observation of the isolates from colonies according to Corbo et al. (2001).

Electrophoretic Analysis of Cheese. The pH 4.6 insoluble $\mathrm{N}$ fractions of Pecorino cheese were analyzed by urea-PAGE using a Protean II xi vertical slab gel unit (BioRad, Watford, UK). The stacking and resolving gel system was prepared as described by Andrews (1983). The gels were stained according to the method 
of Blakesley and Boezi (1977) with Coomassie Brillant Blue G250. The destained gels were acquired by means of the Gel Doc EQ system (BioRad) using a white light conversion screen and analyzed with the Quantity One software (BioRad) to determine the signal intensity (optical density) of the defined bands. Bands were identified by comparison with urea-PAGE electrophoretograms obtained under comparable conditions (Trujillo et al., 2000; Bustamante et al., 2003; Santillo et al., 2007a). Given $100 \%$ the sum of the intensity of the defined bands in a lane, the relative quantity of each band was determined as the percentage of the signal intensity of the defined bands in a lane.

Determination of Plasmin and Plasminogen Contents in Cheese. Plasmin (PL)- and plasminogen (PG)-derived activities were determined in cheese throughout ripening, according to the method of Baldi et al. (1996).

Cheese samples were treated according to a modification of the method of Richardson and Pearce (1981): grated cheese $(5 \mathrm{~g})$ was dispersed in $20 \mathrm{~mL}$ of $0.4 \mathrm{M}$ sodium citrate $(\mathrm{pH} 8.5)$, held at $38^{\circ} \mathrm{C}$ for $15 \mathrm{~min}$, and homogenized in a Stomacher Lab-Blender 400 (PBI International, Milan, Italy) for $5 \mathrm{~min}$. The dissociation of PL and PG from CN micelles was obtained by incubation of the homogenized cheese with $50 \mathrm{~m} M \varepsilon$-aminocaproic acid for $2 \mathrm{~h}$ at room temperature (Korycka-Dahl et al., 1983). A standard curve was prepared to convert PL (Sigma Chemical Co., St. Louis, MO) activity to PL concentration by plotting changes in absorbance against concentrations of PL over a range from 0 to 16 $\mu \mathrm{g} / \mathrm{mL}$. The PL concentration was reported as micrograms per milligram of cheese.

Determination of Rheological Parameters in Cheese. Samples for cheese texture analysis were obtained by cutting a 1-cm-thick slice from the central diameter of the cheese wheel at 30 and $60 \mathrm{~d}$ of ripening. Then, 6 rectangular parallelepipeds, $1 \times 1 \mathrm{~cm}$ thick and $2 \mathrm{~cm}$ long, were obtained from the slide. The cheese samples were left at room temperature for $10 \mathrm{~min}$ before testing. Texture profile analysis was evaluated with an Instron 4301 device (Instron Ltd., High Wycombe, UK) using a modified compression device that avoids transversal elongation of the samples. Each sample underwent 2 cycles of $80 \%$ compression; force $\times$ time data were used to calculate the following parameters: hardness, cohesiveness, springiness, gumminess, chewiness.

Preference and Acceptance Test. A panel of 80 untrained consumers, equally distributed by sex between 25 and $50 \mathrm{yr}$ old, was involved in the analysis; the criterion for recruiting was cheese consumption. Each sample was assigned with 3-digit random numbers, and cheese slices (1.5-mm thick) from the 3 replications of the same batch were mixed randomly so that all replications from the same batch were presented an equal number of times. A glass of water as well as unsalted crispy bread were also provided, and consumers were instructed to take a small bite of bread and a sip of water after each cheese tasting. The cheeses were evaluated for color, smell, and taste liking on a 9-point hedonic scale anchored with "like extremely" and "dislike extremely" and with a neutral center point of "neither like nor dislike" (Peryam and Pilgrim, 1957). The consumers were then asked to give their preference among the cheeses.

\section{Statistical Analysis}

All the variables were tested for normal distribution using the Shapiro-Wilk test (Shapiro and Wilk, 1965). Data on chemical composition, PL and PG, and rheological parameters of cheeses were processed by ANOVA, using the GLM procedure of SAS (SAS Institute, 1999). The model utilized was

$$
\mathrm{y}_{\mathrm{ijk}}=\mu+\alpha_{\mathrm{i}}+\beta_{\mathrm{j}}+(\alpha \beta)_{\mathrm{ij}}+\varepsilon_{\mathrm{ijk}}
$$

where $\mu=$ the overall mean; $\alpha=$ the effect of the type of rennet used for cheesemaking ( $\mathrm{i}=1$ to 3 ); $\beta=$ the effect of time of ripening of cheese $(j=1$ to 5 , for chemical composition, PL, and PG; j = 1 to 2 for rheological parameters); $\alpha \beta=$ the interaction of type of rennet $\times$ time of ripening; and $\varepsilon=$ the error. Preference and acceptance data were analyzed using ANOVA with 1 factor (lamb rennet paste).

Results are presented as the least squares means of the rennet paste characteristics for each type of rennet, and the variability of the data is expressed as the SEM of the mean response throughout the whole trial. The value $P<0.05$ was considered to indicate significant differences.

\section{RESULTS AND DISCUSSION}

\section{Enzymatic and Microbial Characteristics of Lamb Rennet Paste}

Total milk-clotting activity of the rennet paste was 155 international milk-clotting units/g, and chymosin:pepsin ratio was 70:30 in agreement with previous reports of the same authors (Santillo et al., 2007b) for rennet paste obtained from lambs fed a milk diet. Rennet paste displayed a satisfactory microbial quality with the total mesophilic count being less than $5 \mathrm{log}$ $\mathrm{cfu} / \mathrm{g}$ and with no coliforms being detected. Mesophilic lactobacilli (1.18 log cfu/g) and lactococci (2.95 log cfu/ g) were found probably due to the feeding regimen of the lambs slaughtered for rennet production, based on maternal milk. 
Table 1. Yield and gross composition of Gentile di Puglia ewe milk used for Pecorino cheesemaking

\begin{tabular}{lc}
\hline Parameters & Mean values \\
\hline Milk yield, kg/d per ewe & 0.65 \\
Fat, \% wt/wt & 8.55 \\
Protein, \% wt/wt & 5.63 \\
Lactose, \% wt/wt & 4.44 \\
\hline
\end{tabular}

\section{Milk Composition and Cheese Quality}

Milk yield, fat, protein, and lactose content of Gentile di Puglia ewe milk are shown in Table 1. The values from the present experiment were in the range reported for this breed (Ragni et al., 2001; http://www.assonapa.it). Gentile di Puglia is a fine-wooled ovine breed, which gives a small volume of milk. For its high level of nutrients, milk is destined for typical cheese production giving high cheese yields. In the present survey, mean value of cheese yields were $(\mathrm{X} \pm \mathrm{SE}) 17.65 \pm 0.85,18.87$ \pm 1.08 , and $19.79 \pm 0.98 \%$ for RP, RPL, and RPB cheeses, respectively. Fat content in whey from cheesemaking was higher $(P<0.001)$ in the whey from RP $(2.51 \%)$ than from RPL and RPB cheese (1.98 and $1.47 \%$, respectively). Cheese produced using rennet containing probiotic gave fresh cheese curds with greater ability to include fat globules, probably due to lower $\mathrm{pH}$ levels detected in the same cheeses (Figure 1), responsible for accelerating the rearrangement process of $\mathrm{CN}$ particles into a more compact structure.

Lactobacillus acidophilus and Bifidobacterium spp. mix, enumerated on specific media, remained constant during ripening, displaying counts of 8 and $9 \log _{10} \mathrm{cfu} /$ g, respectively. Lactobacillus acidophilus and Lactobacillus paracasei, used as adjunct starters in semihard cheesemaking experiments, turned out to influence the growth dynamics of lactic acid bacteria in cheese during ripening (Bergamini et al., 2006). Under our conditions, the activity of bifidobacteria and $L$. acidophilus may have been directly responsible for the increased growth and survival of mesophilic lactobacilli and lactococci. Mc Brearty et al. (2001) found that Cheddar cheese harboring high levels of $B$. lactis BB-12 throughout ripening also contained higher levels of nonstarter lactic acid bacteria than did the control cheese, possibly as a result of the higher level of available free amino acids in the cheese as a result of more extensive proteolysis, which may act as a nutrient source for lactobacilli. The RPB and RPL showed the highest cell loads of mesophilic lactococci (8.82 and $8.87 \log _{10} \mathrm{cfu} / \mathrm{g}$, respectively; $P<0.001$ ) starting from $7 \mathrm{~d}$ of ripening and of mesophilic lactobacilli (8.95 and $8.45 \log _{10} \mathrm{cfu} / \mathrm{g}$, respectively; $P<$ $0.001)$ starting from $15 \mathrm{~d}$ of ripening. Starting from 30 $\mathrm{d}$, RPB showed the highest $(P<0.001)$ cell loads of mesophilic lactobacilli (8.75 $\left.\log _{10} \mathrm{cfu} / \mathrm{g}\right)$ and lactococci $\left(9.08 \log _{10} \mathrm{cfu} / \mathrm{g}\right)$, whereas RPL showed intermediate values for the same microorganisms $\left(8.06\right.$ and $7.77 \log _{10}$ $\mathrm{cfu} / \mathrm{g}$, respectively). The RP showed the lowest cell loads of mesophilic lactobacilli and lactococci (4.81 and 4.63 $\log _{10} \mathrm{cfu} / \mathrm{g}$, respectively) throughout ripening.

The $\mathrm{pH}$ values were lower in cheese made using paste containing probiotics than in the control cheese $(P<$ 0.001 ) until $30 \mathrm{~d}$. The ripening of the Terrincho sheep milk cheese caused increases in acidity and decreases in $\mathrm{pH}$ up to $30 \mathrm{~d}$ but slight increases between 30 and $60 \mathrm{~d}$ (Park, 2007). Accordingly, RPL and RPB showed a slight, even if not significant, increase in $\mathrm{pH}$ passing from 30 to $60 \mathrm{~d}$. The decrease in $\mathrm{pH}$ values in cheeses obtained using rennet added with probiotic was ascribed to the extensive fermentation of lactose to lactic acid carried out by both the microorganism inoculated in the rennet paste and the endogenous lactic acid bacteria.

\section{Proteolysis in Cheese}

In Table 2 moisture, CN/DM, NCN/TN, and WSN/ $\mathrm{TN}$ are reported. Moisture did not show differences in the experimental cheese curds, whereas it was significantly $(P<0.001)$ influenced by the tested effects as the ripening time advanced. The $\mathrm{RP}$ cheese displayed lower values, whereas RPB cheese had higher values of moisture throughout ripening. The adjunct probiotic bacteria in lamb rennet paste yielded higher cheese moisture, probably due to the greater production of lactic acid. High production of lactic acid in the initial stages of processing may cause the coagulum to lose more $\mathrm{Ca}$ into the whey and result in a lower ability of the curd to contract and thus expel water in subsequent cheese aging (Jimenez-Marquez et al., 2005).

Most of the coagulant added to the milk is lost in the whey; at most, $15 \%$ of the rennet activity added to the milk remains in the curd after manufacture, depending on factors such as type of coagulant, ratio of different enzymes, cooking temperature, cheese variety, and moisture level of the final cheese (Sousa et al., 2001). In the present trial, cheese obtained using rennet paste supplemented with probiotic bacteria displayed a higher primary proteolysis as suggested by the higher rate of disappearance of $\mathrm{CN}$ in those cheeses than in the control cheese during the first week of ripening. The major moisture reduction in the control cheese between 1 and $7 \mathrm{~d}$ could explain the differences in the $\mathrm{CN}$ content; when the water loss is high, there is a concentration of total solids in the cheese matrix. Starting from $30 \mathrm{~d}$, RPL cheese displayed $\mathrm{CN}$ content comparable to $\mathrm{RP}$ cheese despite its higher lactic acid bacteria cell loads; in fact, enzymes released by $L$. acidophilus 


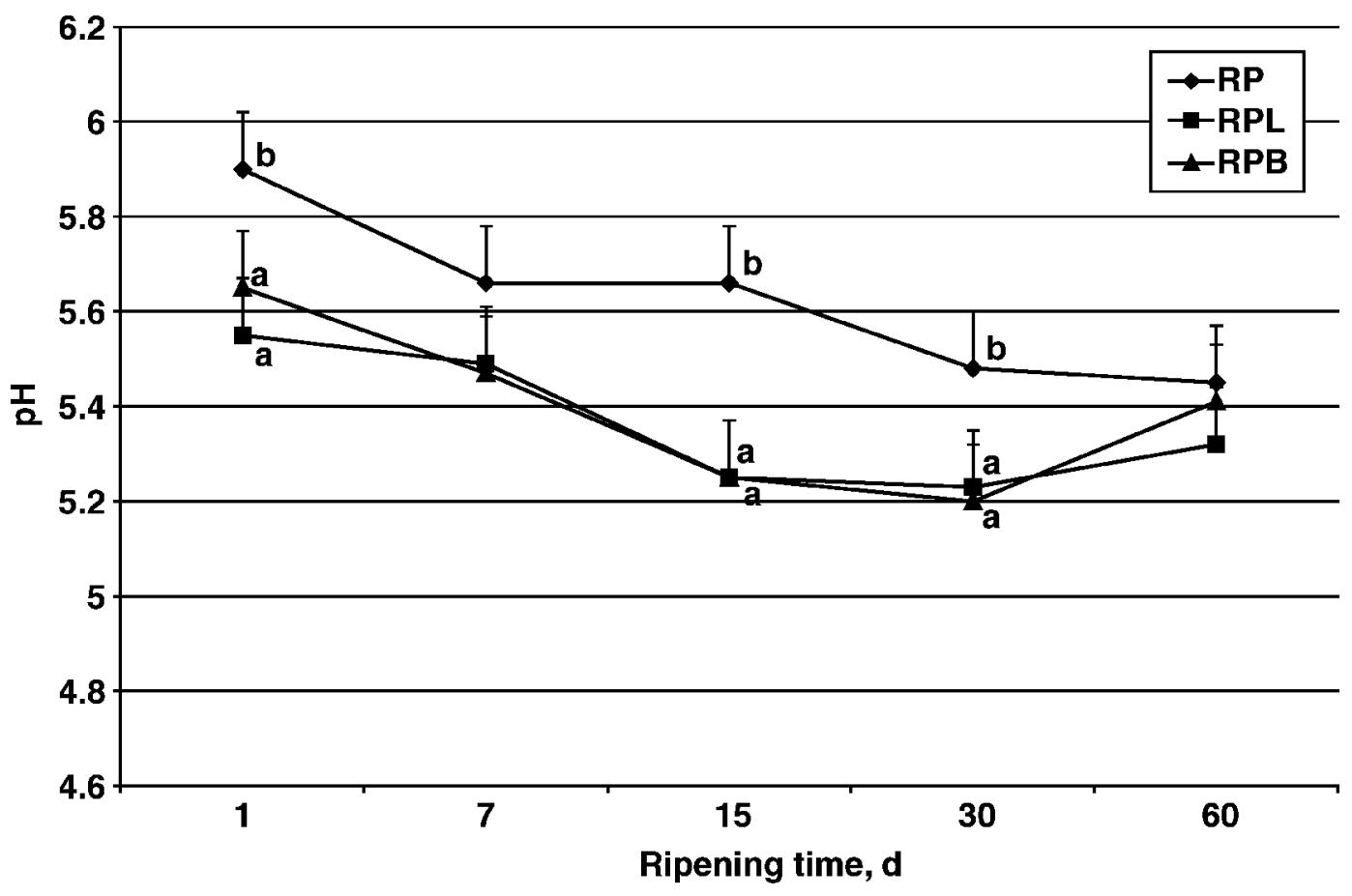

Figure 1. Changes in $\mathrm{pH}$ in cheese manufactured using traditional lamb rennet paste and lamb rennet paste containing probiotic during ripening. RP: cheese manufactured using traditional lamb rennet paste; $\mathbf{R P L}$ : cheese manufactured using lamb rennet paste containing Lactobacillus acidophilus (LA-5); $\mathbf{\Delta}$ RPB: cheese manufactured using lamb rennet paste containing Bifidobacterium lactis (BB-12) and Bifidobacterium longum (BB-46), ${ }^{\mathrm{a}, \mathrm{b}}$ Means with different letters differ at $P<0.05$, for each time of ripening.

could have been expected to act as a greater proteolysis in the RPL cheese. The RPB cheese displayed the lowest $\mathrm{CN}$ content starting from $30 \mathrm{~d}$ of ripening. It is well known that lactic acid bacteria are one of the proteolytic agents in cheese during ripening (Fox, 2003). The choice of the lactic acid bacteria strain seems to play an important role in cheese proteolysis. In RPB cheese, the enzymes associated to both Bifidobacterium mix and lactic acid bacteria carried out a greater degradation of $\mathrm{CN}$ matrix leading to an accelerated cheese ripening.

The majority of $\mathrm{pH} 4.6$ soluble $\mathrm{N}$ is made up of largeand medium-sized peptides produced by the action of residual rennet and PL, but it also contains numerous small-sized peptides, free amino acids, and their catabolites produced by microflora (Fallico et al., 2005). In this trial, no differences were found in NCN/TN and WSN/TN fractions at $1 \mathrm{~d}$ among the experimental cheeses, whereas, as ripening advanced, RPB showed the highest, RPL intermediate, and RP the lowest $(P<$ 0.001 ) values, confirming the greater degradation of CN matrix in cheese obtained using lamb rennet paste containing bifidobacteria. In Canestrato pugliese cheese with added bifidobacteria, more pronounced imino-, amino-, and dipeptidase activities were found together with a higher concentration of $\mathrm{pH} 4.6$ soluble N/ TN (Corbo et al., 2001). The greater proteolysis was also confirmed by the electrophoretic analysis of the experimental cheeses, RPB showing a higher amount of $\alpha_{\mathrm{s}}$-CN degradation products starting from $30 \mathrm{~d}$ of ripening (Figure 2). A progressive and significant increase in $\gamma$-CN and $\alpha_{\mathrm{s}}$-CN degradation products took place in all cheeses during ripening, the latter fraction being quantitatively higher as a result of a more extensive degradation occurring in $\alpha_{\mathrm{s}}-\mathrm{CN}$ than in $\beta$-CN fraction. It has been reported that $\beta$-CN is resistant to hydrolysis during the ripening of most cheese varieties. Furthermore, when animal rennet was used in internal bacterially ripened cheese varieties, proteolysis of $\beta$ CN was less than that of $\alpha_{\mathrm{s}} \mathrm{C}$ CN (Fox, 1993).

The contribution of PL to proteolysis is relevant to cheese quality through hydrolysis of CN (Kelly and McSweeney, 2002), and the increase in the PL activity in cheeses, as a result of PG activation, ameliorates the flavor and the overall quality of cheese (Farkye and Landkammer, 1992). Plasmin, PG concentration, and PG:PL ratio are reported in Table 3. Plasmin was the highest $(P<0.001)$ in RPB up to $15 \mathrm{~d}$ of ripening, whereas no differences were found among cheeses for $\mathrm{PG}$, except at $7 \mathrm{~d}$ with the highest values being reported in RPB cheese. At $1 \mathrm{~d}$ of ripening, the rate of $\mathrm{PG}$ conversion was the highest $(P<0.001)$ in RPB due to the highest $(P<0.05)$ amount of $\beta$-CN $(40.41 \%$ vs. $36.71 \%$ 
Table 2. Chemical composition of cheese manufactured using traditional lamb rennet paste and lamb rennet paste containing probiotic during ripening

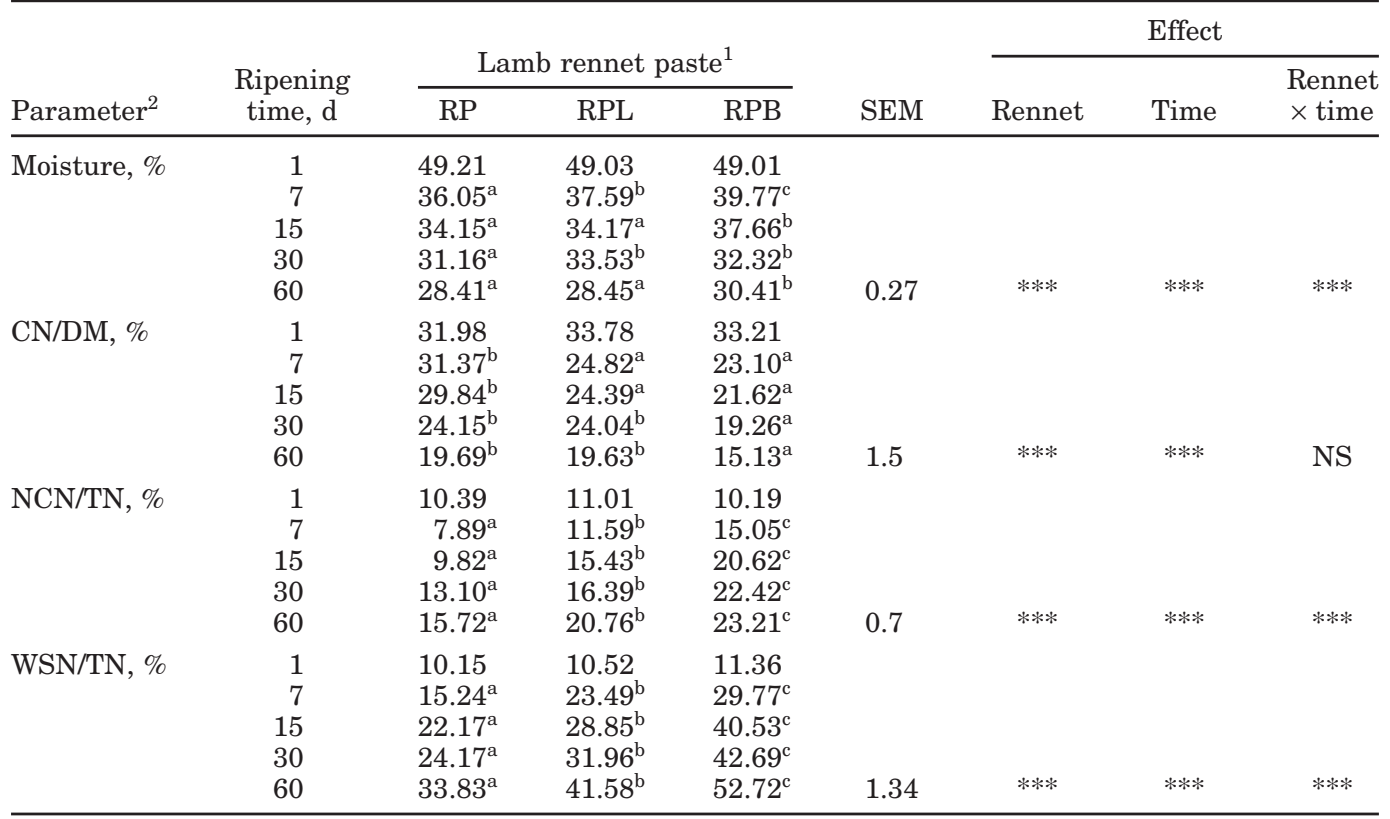

${ }^{\mathrm{a}-\mathrm{c}}$ Means with different superscripts differ for each item in rows $(P<0.05)$.

${ }^{1} \mathrm{RP}=$ cheese manufactured using traditional lamb rennet paste; $\mathrm{RPL}=$ cheese manufactured using lamb rennet paste containing Lactobacillus acidophilus (LA-5); RPB = cheese manufactured using lamb rennet paste containing Bifidobacterium lactis (BB-12) and Bifidobacterium longum (BB-46).

${ }^{2} \mathrm{NCN} / \mathrm{TN}=$ non-CN/total N; WSN/TN = water-soluble N/total $\mathrm{N}$.

$* * * P<0.001$.

and $37.4 \%$ in $\mathrm{RP}$ and RPL, respectively), which is the preferred substrate for PL. The evolution of $\gamma-\mathrm{CN}$ fraction in cheese during ripening is shown in Figure 3. This fraction was higher $(P<0.001)$ in RP than in $\mathrm{RPB}$ in the time points evaluated; this could appear in disagreement with PL content in the same cheeses. It is noteworthy that the percentage of $\gamma-\mathrm{CN}$ in $\mathrm{RP}$ and RPL cheeses at $60 \mathrm{~d}$ was 2 -fold higher than in the cheese curd of the same group, whereas the mentioned parameter was 3 -fold higher in RPB cheese than in the corresponding fresh curd, as a result of the higher hydrolysis carried out by the higher PL content in the latter cheese. The major increase of $\gamma$-CN in RPB cheese could be an outcome of the highest PL content in the same cheese, although these 2 parameters are not synchronized. The percentage of $\gamma$-CN decreased from 30 to $60 \mathrm{~d}$ in all cheeses as the peptides produced by PL activity were further hydrolyzed to small peptides and amino acids.

\section{Rheological Parameters in Cheese}

Texture plays an important role in the quality of cheese and depends on cheese structure (Pinho et al., 2004; Park, 2007). Rheological parameters of the experimental cheeses at 30 and $60 \mathrm{~d}$ of ripening are reported in Table 4. The RPB cheese at both 30 and $60 \mathrm{~d}$ showed lower values for all parameters than RP cheese, whereas RPL behaved differently with increasing ripening time: rheological profile was comparable to RPB at $30 \mathrm{~d}$, but all the parameters markedly increased with time to such an extent that they were not different between RPL and RP cheese at $60 \mathrm{~d}$ of ripening. It has been shown that high acidity, protein, and total solids contents generally make the cheese harder and less easily deformed (Kehagias et al., 1995). It is worth noticing that, in the present experiment, cheeses displaying lower moisture were found to be harder accordingly. The higher hardness recorded in RP cheese could also be ascribed to the lower proteolysis; Park (2007) reported a high correlation between those parameters due to proteolysis of $\mathrm{CN}$ disrupting the protein bonds with a more flexible cheese matrix. The $\mathrm{pH}$ also plays an important role in cheese texture; as the $\mathrm{pH}$ of cheese curds decreases, there is a concomitant loss of colloidal calcium phosphate from the $\mathrm{CN}$ submicelles and, below about $\mathrm{pH}$ 5.5, a progressive dissociation of the submicelles into smaller CN aggregates (Lebecque et al., 2001). The $\mathrm{pH}$ values of RPB and RPL cheeses were lower than 5.5 starting from $7 \mathrm{~d}$ of ripening, whereas $\mathrm{pH}$ decreased slower in the control cheese with increasing 


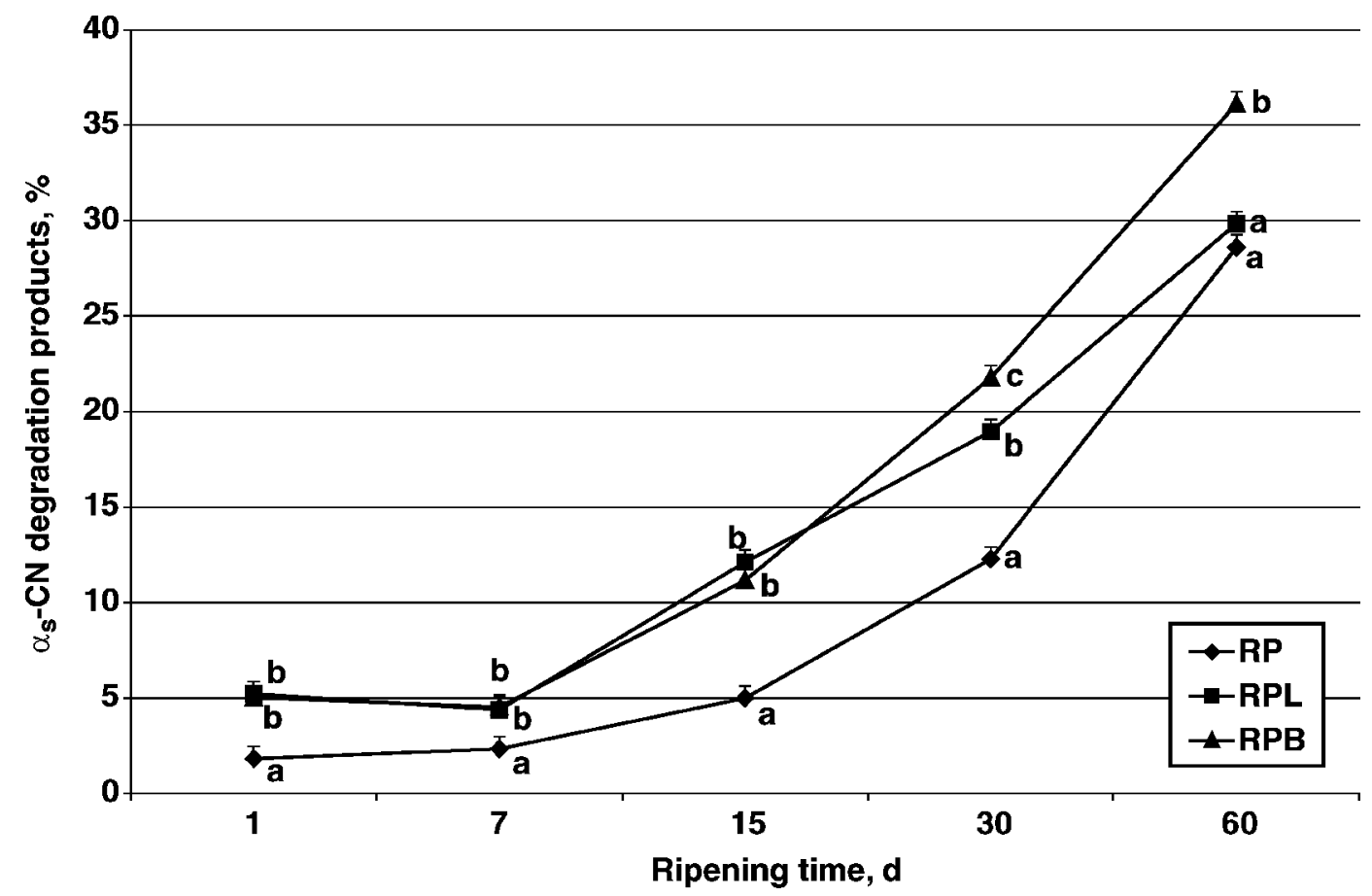

Figure 2. Evaluation of $\alpha_{\mathrm{s}}-\mathrm{CN}$ degradation products in cheese manufactured using traditional lamb rennet paste and lamb rennet paste containing probiotic during ripening. - RP: cheese manufactured using traditional lamb rennet paste; $\mathbf{R P L}$ : cheese manufactured using lamb rennet paste containing Lactobacillus acidophilus (LA-5); $\mathbf{\Delta}$ RPB: cheese manufactured using lamb rennet paste containing Bifidobacterium lactis (BB-12) and Bifidobacterium longum (BB-46). ${ }^{a-c}$ Means with different superscripts differ at $P<0.05$, for each time of ripening.

Table 3. Plasmin and plasminogen concentration and plasminogen-plasmin ratio in cheese manufactured using traditional lamb rennet paste and lamb rennet paste containing probiotic during ripening

\begin{tabular}{|c|c|c|c|c|c|c|c|c|}
\hline \multirow[b]{3}{*}{ Parameter } & \multirow{3}{*}{$\begin{array}{l}\text { Ripening } \\
\text { time, d }\end{array}$} & \multirow{2}{*}{\multicolumn{3}{|c|}{ Lamb rennet paste $^{1}$}} & \multirow[b]{3}{*}{ SEM } & \multicolumn{3}{|c|}{ Effect } \\
\hline & & & & & & \multirow[b]{2}{*}{ Rennet } & \multirow[b]{2}{*}{ Time } & \multirow{2}{*}{$\begin{array}{l}\text { Rennet } \\
\times \text { time }\end{array}$} \\
\hline & & $\mathrm{RP}$ & RPL & $\mathrm{RPB}$ & & & & \\
\hline \multirow[t]{5}{*}{ Plasmin, $\mu \mathrm{g} / \mathrm{mg}$} & 1 & $0.141^{\mathrm{a}}$ & $0.069^{\mathrm{a}}$ & $0.212^{\mathrm{b}}$ & & & & \\
\hline & 7 & $0.303^{b}$ & $0.114^{\mathrm{a}}$ & $0.374^{\mathrm{c}}$ & & & & \\
\hline & 15 & $0.157^{\mathrm{a}}$ & $0.143^{\mathrm{a}}$ & $0.385^{b}$ & & & & \\
\hline & 30 & $0.171^{\mathrm{a}}$ & $0.309^{b}$ & $0.141^{\mathrm{a}}$ & & & & \\
\hline & 60 & 0.152 & 0.175 & 0.161 & 0.02 & $* * *$ & $* * *$ & $* * *$ \\
\hline \multirow[t]{5}{*}{ Plasminogen, $\mu \mathrm{g} / \mathrm{mg}$} & 1 & 0.172 & 0.215 & 0.19 & & & & \\
\hline & 7 & $0.047^{\mathrm{a}}$ & $0.037^{\mathrm{a}}$ & $0.114^{b}$ & & & & \\
\hline & 15 & 0.057 & 0.076 & 0.064 & & & & \\
\hline & 30 & 0.044 & 0.08 & 0.038 & & & & \\
\hline & 60 & 0.067 & 0.065 & 0.022 & 0.02 & NS & $* * *$ & NS \\
\hline \multirow[t]{5}{*}{ Plasminogen:plasmin } & 1 & $1.22^{\mathrm{b}}$ & $3.11^{\mathrm{c}}$ & $0.90^{\mathrm{a}}$ & & & & \\
\hline & 7 & 0.15 & 0.35 & 0.31 & & & & \\
\hline & 15 & 0.37 & 0.55 & 0.15 & & & & \\
\hline & 30 & 0.26 & 0.26 & 0.28 & & & & \\
\hline & 60 & 0.44 & 0.38 & 0.13 & 0.16 & $* * *$ & $* * *$ & $* * *$ \\
\hline
\end{tabular}

${ }^{\mathrm{a}-c}$ Means with different superscripts differ for each item in rows $(P<0.05)$.

${ }^{1} \mathrm{RP}=$ cheese manufactured using traditional lamb rennet paste; $\mathrm{RPL}=$ cheese manufactured using lamb rennet paste contining Lactobacillus acidophilus (LA-5); RPB = cheese manufactured using lamb rennet paste containing Bifidobacterium lactis (BB-12) and Bifidobacterium longum (BB-46).

$* * * P<0.001$ 


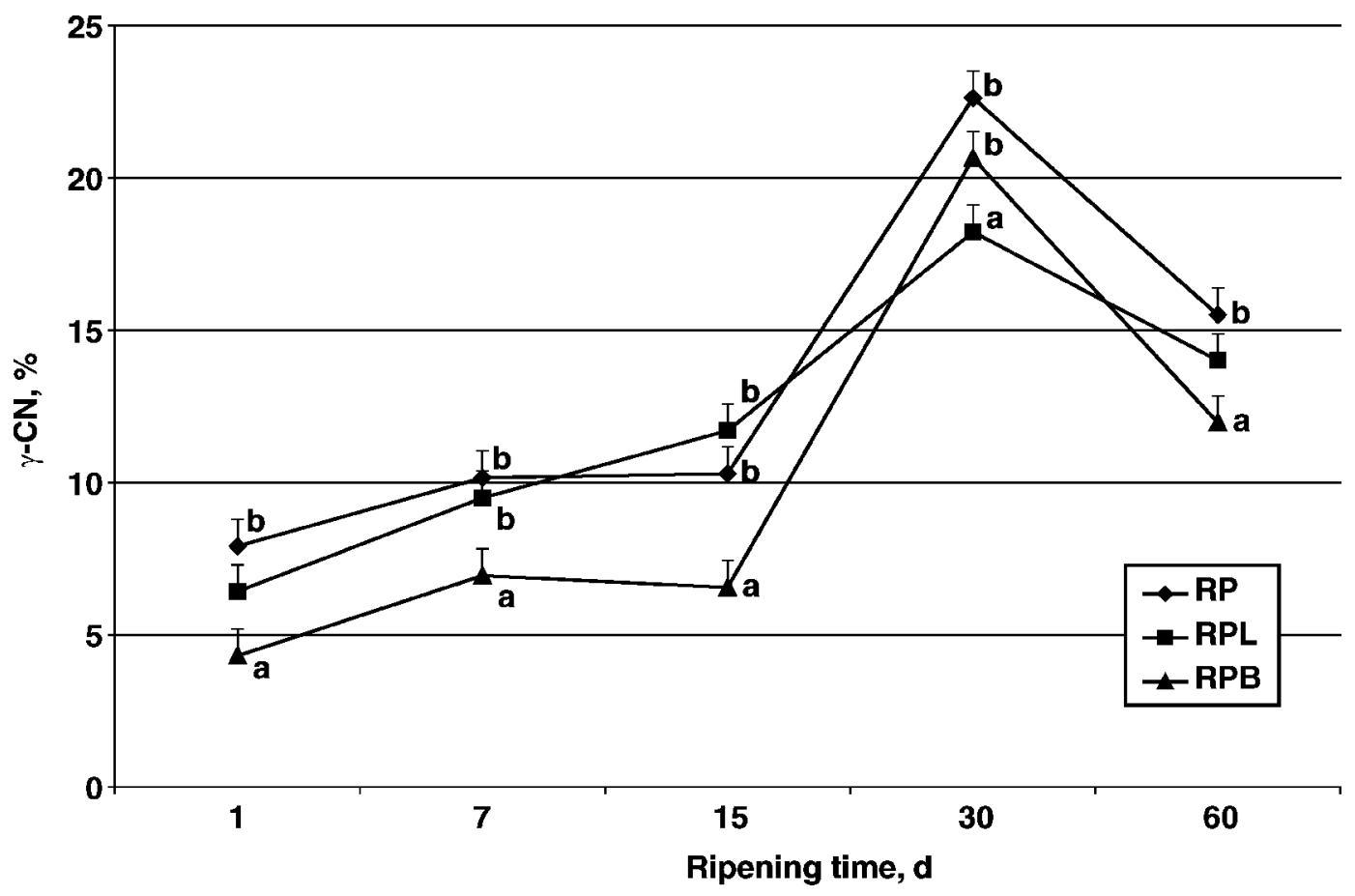

Figure 3. Evolution of $\gamma$-CN in cheese manufactured using traditional lamb rennet paste and lamb rennet paste containing probiotic during ripening. RP: cheese manufactured using traditional lamb rennet paste; $\mathbf{R P L}$ : cheese manufactured using lamb rennet paste containing Lactobacillus acidophilus (LA-5); $\Delta$ RPB: cheese manufactured using lamb rennet paste containing Bifidobacterium lactis (BB12 ) and Bifidobacterium longum (BB-46). ${ }^{\text {a,b }}$ Means with different superscripts differ for each item at $P<0.05$, for each time of ripening.

ripening, being the aforementioned value reached after $30 \mathrm{~d}$. Despite the comparable $\mathrm{pH}$ values of RPL and $\mathrm{RPB}$ cheese, index of metabolic activity of lactic acid bacteria in cheese, the lower hardness in RPB at the end of ripening could be ascribed to the greater proteolysis observed in cheese harboring the Bifidobacterium mix.

\section{Preference and Acceptance Test in Cheese}

Preference and acceptance tests were performed to evaluate the degree of liking of the experimental cheeses. Color, smell, and taste liking of the cheeses are presented in Table 5. No differences were identified

Table 4. Rheological parameters of cheese manufactured using traditional lamb rennet paste and lamb rennet paste containing probiotic at 30 and $60 \mathrm{~d}$ of ripening

\begin{tabular}{|c|c|c|c|c|c|c|c|c|}
\hline \multirow[b]{3}{*}{ Parameter } & \multirow{3}{*}{$\begin{array}{l}\text { Ripening } \\
\text { time, d }\end{array}$} & \multirow{2}{*}{\multicolumn{3}{|c|}{ Lamb rennet paste $^{1}$}} & \multirow[b]{3}{*}{ SEM } & \multicolumn{3}{|c|}{ Effect } \\
\hline & & & & & & & & Rennet \\
\hline & & $\mathrm{RP}$ & RPL & RPB & & Rennet & Time & $\times$ time \\
\hline \multirow[t]{2}{*}{ Hardness, $\mathrm{N}$} & 30 & $31.58^{\mathrm{b}}$ & $19.76^{\mathrm{a}}$ & $9.17^{\mathrm{a}}$ & & & & \\
\hline & 60 & $35.57^{\mathrm{b}}$ & $37.51^{\mathrm{b}}$ & $25.32^{\mathrm{a}}$ & 3.66 & $*$ & * & NS \\
\hline \multirow[t]{2}{*}{ Cohesiveness } & 30 & $0.21^{\mathrm{b}}$ & $0.14^{\mathrm{a}}$ & $0.08^{\mathrm{a}}$ & & & & \\
\hline & 60 & $0.18^{\mathrm{b}}$ & $0.15^{\mathrm{b}}$ & $0.06^{\mathrm{a}}$ & 0.02 & $* * *$ & NS & NS \\
\hline \multirow[t]{2}{*}{ Springiness, $\mathrm{mm}$} & 30 & $7.8^{\mathrm{b}}$ & $7.57^{\mathrm{a}}$ & $7.32^{\mathrm{a}}$ & & & & \\
\hline & 60 & $7.89^{c}$ & $7.13^{\mathrm{b}}$ & $5.1^{\mathrm{a}}$ & 0.14 & $* *$ & $*$ & $*$ \\
\hline \multirow[t]{2}{*}{ Gumminess, $\mathrm{N}$} & 30 & $0.57^{\mathrm{b}}$ & $0.23^{\mathrm{a}}$ & $0.07^{\mathrm{a}}$ & & & & \\
\hline & 60 & $0.58^{b}$ & $0.57^{\mathrm{b}}$ & $0.19^{\mathrm{a}}$ & 0.1 & $* * *$ & $*$ & NS \\
\hline \multirow[t]{2}{*}{ Chewiness, $\mathrm{N} \times \mathrm{mm}$} & 30 & $4.1^{\mathrm{b}}$ & $1.7^{\mathrm{a}}$ & $0.68^{\mathrm{a}}$ & & & & \\
\hline & 60 & $10.03^{b}$ & $10.11^{\mathrm{b}}$ & $1.45^{\mathrm{a}}$ & 0.46 & $* * *$ & $* * *$ & $* * *$ \\
\hline
\end{tabular}

${ }^{\mathrm{a}-\mathrm{c}}$ Means with different superscripts differ for each item in rows $(P<0.05)$.

${ }^{1} \mathrm{RP}=$ cheese manufactured using traditional lamb rennet paste; $\mathrm{RPL}=$ cheese amnufactured using lamb rennet paste containing Lactobacillus acidophilus (LA-5); RPB = cheese manufactured using lamb rennet paste containing Bifidobacterium lactis (BB-12) and Bifidobacterium longum (BB-46).

$* P<0.05 ; * * P<0.01 ; * * * P<0.001$. 
Table 5. Acceptance of cheese manufactured using traditional lamb rennet paste and lamb rennet paste containing probiotic at $60 \mathrm{~d}$ of ripening

\begin{tabular}{llllll}
\hline & \multicolumn{3}{c}{ Lamb rennet paste $^{1}$} & & Effect \\
\cline { 2 - 4 } Parameter & RP & RPL & RPB & SEM & Rennet \\
\hline Color & $6.78^{\mathrm{b}}$ & $6.06^{\mathrm{a}}$ & $6.78^{\mathrm{b}}$ & 0.23 & $*$ \\
Smell & 6.59 & 6.31 & 6.84 & 0.24 & NS \\
Taste & 6.25 & 6.81 & 6.31 & 0.27 & NS \\
\hline
\end{tabular}

${ }^{\mathrm{a}, \mathrm{b}}$ Means with different superscripts differ for each item in rows $(P<0.05)$.

${ }^{1} \mathrm{RP}=$ cheese manufactured using traditional lamb rennet paste; $\mathrm{RPL}=$ cheese manufactured using lamb rennet paste containing Lactobacillus acidophilus (LA-5); RPB = cheese manufactured using lamb rennet paste containing Bifidobacterium lactis (BB-12) and Bifidobacterium longum (BB-46).

$* P<0.05$.

by consumers for smell and taste, whereas RPL received the lowest score $(P<0.05)$ for color. Preference test did not evidence differences among cheeses. Lamb rennet paste containing probiotics used for traditional Pecorino cheese production must transfer viable cells into the cheese matrix as well as maintain organoleptic characteristic similar to conventional cheese. Although differences in proteolytic patterns were detected among the cheeses at the end of ripening, this did not account for differences in product liking. Addition of bifidobacteria to Gouda (Gomes et al., 1995) and Cottage (Blanchette et al., 1996) cheeses had a negative effect on cheese flavor and resulted in a reduced acceptability with respect to the traditional cheeses. In Cheddar cheese, Ong et al. (2007) found that acceptability of probiotic cheese is strain-dependent; thus, the evaluation of the acceptability of cheese is crucial when selecting probiotic strains to be used in the cheesemaking process.

\section{CONCLUSIONS}

Probiotic bacteria cultures, LA-5, BB-12, and BB-46, were incorporated into lamb rennet paste used for Pecorino cheese manufactured according to a traditional protocol. Probiotics remained viable at high levels in cheese throughout ripening and influenced the proteolytic and rheological features of ovine cheese.

During ripening, cheese obtained using rennet with bifidobacteria showed greater proteolysis and lower hardness owing to higher $\mathrm{CN}$ degradation carried out by proteolytic enzymes associated to both Bifidobacterium mix and endogenous lactic acid microflora. Although differences in proteolyic patterns were found among treatments, this did not account for differences in smell and taste scores. The traditional lamb rennet paste containing probiotic bacteria can be used in the production of functional cheese, which maintain the acceptable quality of the typical Pecorino cheese.

\section{ACKNOWLEDGMENTS}

We would like to thank Concetta Perilli and Stefano D'Urso (Department PrIME, University of Foggia, Italy) for expert technical assistance.

\section{REFERENCES}

Addis, M., G. Piredda, M. Pes, R. Di Salvo, M. F. Scintu, and A. Pirisi. 2005. Effect of three different lamb rennets on lipolysis of the PDO Pecorino Romano Cheese. Int. Dairy J. 15:563-569.

Andrews, A. T. 1983. Proteinases in normal bovine milk and their action on caseins. J. Dairy Res. 50:45-55.

Baldi, A., G. Savoini, F. Cheli, F. Fantuz, E. Senatore, L. Bertocchi, and I. Politis. 1996. Changes in plasmin-plasminogen activator system in milk from Italian Friesian herds. Int. Dairy J. 6:1045-1053.

Bergamini, C. V., E. R. Hynes, and C. A. Zalazar. 2006. Influence of probiotic bacteria on the proteolysis profile of a semi-hard cheese. Int. Dairy J. 16:856-866.

Blakesley, R. W., and J. A. Boezi. 1977. A new staining technique for proteins in polyacrylamide gels using Coomassie Brilliant Blue G250. Anal. Biochem. 82:580-582.

Blanchette, L., D. Roy, G. Bèlanger, and S. F. Gauthier. 1996. Production of Cottage cheese using dressing fermented by bifidobacteria. J. Dairy Sci. 79:8-15.

Bustamante, M., M. Virto, I. Aramburu, L. J. R. Barron, F. J. PérezElortondo, M. Albisu, and M. de Renobales. 2003. Lamb rennet paste in ovine cheese (Idiazabal) manufacture. Proteolysis and relationship between analytical and sensory parameters. Int. Dairy J. 13:547-557.

Chessa, S., P. Bolla, C. Dario, E. Pieragostini, and A. Caroli. 2003. Genetic polymorphisms of milk proteins from Gentile di Puglia ovine breed: Isoelectrofocusing approach. Sci. Tecn. Latt. Cas. 54:191-198.

Corbo, M. R., M. Albenzio, M. De Angelis, A. Sevi, and M. Gobbetti 2001. Microbiological and biochemical properties of Pecorino hard cheese supplemented with Bifidobacteria. J. Dairy Sci. 84:551561.

Fahmy, M. H., and J. N. B. Shrestha. 2003. Sheep breeds. Page 598 in Encyclopedia of Dairy Sciences. Vol. 2. H. Roginski, J. W. Fuqay, P. F. Fox, ed. MPG Books Ltd., Bodmin, Cornwall, UK.

Fallico, V., P. L. H. McSweeney, J. Horne, C. Pediliggieri, J. A. Hannon, S. Carpino, and G. Licitra. 2005. Evaluation of bitterness in Ragusano cheese. J. Dairy Sci. 88:1288-1300.

Farkye, Y. N., and C. F. Landkammer. 1992. Milk plasmin activity influence on Cheddar cheese quality during ripening. J. Food Sci. 57:622-639.

Fox, P. F. 1993. Cheese: An overview. Pages 1-36 in Cheese: Chemistry, Physics and Microbiology. Vol. 1. P. F. Fox, ed. Chapman \& Hall, London, UK. 
Fox, P. F. 2003. Biochemistry of cheese ripening. Page 323 in Encyclopedia of Dairy Sciences. Vol. 1. H. Roginski, J. W. Fuquay, P. F. Fox, ed. MPG Books Ltd., Bodmin, Cornwall, UK.

Gomes, A. M. P., F. X. Malcata, F. A. M. Klaver, and H. J. Grande. 1995. Incorporation and survival of Bifidobacterium spp. strain Bo and Lactobacillus acidophilus strain $\mathrm{Ki}$ in a cheese product. Neth. Milk Dairy J. 49:71-95.

Gripon, J. C., M. J. Desmazeaud, D. Le Bars, and J. L. Bergere. 1975. Etude du role des micro-organismens et des enzymes au cours de la maturation des fromages. Lait 548:502-515.

IDF. 1986. Cheese and processed cheese products. Determination of dry matter. IDF Standard No 4. FIL-IDF, Brussels, Belgium.

IDF. 1989. Determination of pH. Standard No 115A. FIL-IDF, Brussels, Belgium.

IDF. 1997. Milk and milk products. Ovine and caprine rennets. Determination of total milk-clotting activity. Standard No. 157a. FILIDF, Brussels, Belgium.

IDF. 2006. Milk and milk products. Ovine and caprine rennets. Determination of total milk-clotting activity. Standard No. 199. FILIDF, Brussels, Belgium.

Jimenez-Marquez, S. A., J. Thibault, and C. Lacroix. 2005. Prediction of moisture in cheese of commercial production using neural networks. Int. Dairy J. 15:1156-1174.

Kehagias, C., S. Koulouris, A. Samona, and S. Malliou. 1995. Effect of various starters on the quality of cheese in brine. Food Microbiol. 12:413-420.

Kelly, A. L., and P. L. H. McSweeney. 2002. Indigenous proteinases in milk. Pages 494-519 in Advanced Dairy Chemistry. Vol. 2. F. Fox and P. L. H. McSweeney, ed. Kluwer Acad./Plenum Publ., New York, NY.

Korycka-Dahl, M., B. Ribadeau Dumas, N. Chene, and J. Martal. 1983. Plasmin activity in milk. J. Dairy Sci. 66:704-711.

Lebecque, A., A. Laguet, M. F. Devaux, and E. Dufour. 2001. Delineation of the texture of Salers cheese by sensory analysis and physical methods. Lait 81:609-623.

Mc Brearty, S., R. P. Ross, G. F. Fitzgerald, J. K. Collins, J. M. Wallace, and C. Stanton. 2001. Influence of two commercially available bifidobacteria cultures on Cheddar cheese quality. Int. Dairy J. 11:599-610.

Ong, L., A. Henriksson, and N. P. Shah. 2007. Chemical analysis and sensory evaluation of Cheddar cheese produced with Lactobacil- lus acidophilus, Lb. casei, Lb. paracasei or Bifidobacterium sp. Int. Dairy J. 17:937-945.

Park, Y. W. 2007. Rheological characteristics of goat and sheep milk. Small Rumin. Res. 68:73-87.

Peryam, D. R., and F. J. Pilgrim. 1957. Hedonic scale method of measuring food preferences. Food Technol. 11:9-14.

Pinho, O., E. Mendes, M. M. Alves, and I. M. Ferreira. 2004. Chemical, physical, and sensorial characteristics of "Terrincho" ewe cheese: Changes during ripening and intravarietal comparison. J. Dairy Sci. 87:249-257.

Ragni, M., A. Vicenti, L. Melodia, S. Dimatteo, R. Sottili, and G. Vonghia. 2001. A comparison of the quality and quantity of milk produced by different sheep breeds reared in marginal areas. Pages 187-194 in Proc. Ital. Meet. Parliamo di Zootecnia e Sviluppo Sostenibile. Univ. Torino, Grugliasco, Italy.

Richardson, B. C., and K. N. Pearce. 1981. The determination of plasmin in dairy products. N. Z. J. Dairy Sci. Technol. 16:209-220.

Ross, R. P., G. Fitzgerald, K. Collins, and C. Stanton. 2002. Cheese delivering biocultures- probiotic cheese. Aust. J. Dairy Technol. 57:71-78.

Santillo, A., M. Caroprese, R. Marino, A. Muscio, A. Sevi, and M. Albenzio. 2007a. Influence of lamb rennet paste on chemical and enzymatic characteristics of Pecorino Foggiano cheese. Int. Dairy J. 17:535-546.

Santillo, A., M. Quinto, M. Dentico, A. Muscio, A. Sevi, and M. Albenzio. 2007b. Rennet paste from lambs fed a milk substitute supplemented with Lactobacillus acidophilus: Effects on lipolysis in ovine cheese. J. Dairy Sci. 90:3134-3142.

SAS Institute. 1999. SAS/STAT User's Guide (Version 8.1). SAS Inst, Cary, NC.

Shah, N. P. 2007. Functional cultures and health benefits. Int. Dairy J. 17:1262-1277.

Shapiro, S. S., and M. Wilk. 1965. An analysis of variance test for normality. Biometrika 52:591-601.

Sousa, M. J., Y. Ardö, and P. H. L. McSweeney. 2001. Advances in the study of proteolysis during cheese ripening. Int. Dairy J. $11: 327-345$.

Stadhouders, J. 1960. The hydrolysis of protein during ripening of Dutch cheese. The enzymes of the bacteria involved. Neth. Milk Dairy J. 14:106-110.

Trujillo, A. J., B. Guamis, J. Laencina, and M. B. López. 2000. Proteolytic activities of some milk clotting enzymes on ovine casein. Food Chem. 71:449-457. 